\title{
Looking at urban regeneration from the viewpoint of urban safety: Istanbul's crime areas
}

\author{
P. Ozden \\ Department of Public Administration, Istanbul University, Turkey
}

\begin{abstract}
In today's metropolitan cities, urban crimes are increasing continuously. The growth of urban economies are becoming more and more a disadvantage of the cities and, as a result thereof, the occurrence of urban poverty and the rapid increase in the ratio of such poverty plays the most important role in the increase of urban crime. Thus, every day many more urban people become the target and victim of various urban crimes. Today, more than half of all crimes in Turkey are committed in Istanbul. This percentage increased steadily within the past years. There is no doubt that urban decay and the deprived areas within the city played a great role in the increase of crimes. Particularly the urban decay processes experienced in various regions of the city prepare the basis for crime. In this study, the crime phenomenon in the districts of Beyoğlu and Ümraniye, the districts with the highest crime ratio within the metropole city of Istanbul, will be analyzed using social, demographical, locational and criminological data, overlapping the socio-economic data with the locational data. The study will also be supported with the results of a similar study performed previously on the districts of Fatih and Üsküdar.
\end{abstract}

Keywords: urban regeneration, urban safety, urban decay, deprivation areas.

\section{Introduction}

Urban security has been a matter of interest not only for police forces but also for town planners since the 1950's. The inequalities in income distribution, internal migration and problems of urbanization caused by migration, unfair spatial sharing, relative social deprivation and disintegration in the city, directly affect the society and urban landscape and create a suitable background for crime. 
Although crime is a universal phenomenon it is possible to conclude that the weight and pressure of crime gradually increase in large cities where social pressures decrease and the sense of belonging weakens. Numerous theorems on crime will not be deliberated upon as the scope of this study is limited. Notwithstanding the foregoing, the theorem of lack of social organization, taking as a basis the simplified city model of the Chicago school, illustrating the relationship between urban space and crime in a very clear manner, will be the focus point of this study. Districts of Üsküdar and Fatih, the areas previously studied, were tested within the framework of this theorem and the conclusions reached were quite overlapping. According to the theorem, the city grows with the pressure of the center and by means of expansion towards the outside. In this process, the outer circle undergoes regeneration with the effect of the inner circle. Similarly, the physical, economic and social conditions get worse gradually. The crime rate decreases as one moves further away from the center and increases in regions closer to the center; regions where rents are low, the tendency of decreasing population exists and the level of prosperity decreases. The theorem foresees that intensive crime areas are determined by using spatial data and that the socioeconomic, cultural and physical conditions of criminals / suspects should be displayed by masters.

The areas where urban crime is most intense are areas of deprivation and social marginalization. According to Adaman and Keyder [1], the squatter areas and poor neighborhoods in the city, areas of urban deprivation, are areas that are the most defenseless against the processes of social marginalization. These regions overlap to a significant extent with areas where crime rates are highest, supporting the finding in the study of the Chicago School. In this present study, the theorem will be tested in the sampling areas of Beyoğlu and Ümraniye, which are significant locations of urban deprivation and social marginalization. Proposals will be made to decrease the urban crime ratio by using urban regeneration as a tool.

\section{Crime, urban area and regeneration}

Düzgün [2] notes that the approach developed by Jacobs in 1964 that, "People will find the opportunity to monitor each other as activities of people increase in the cities, which may decrease crimes", has been used as the basis in all urban design and crime prevention theories developed to date. Duzgun further notes that a comprehensive point of view on the use of space in crime prevention was developed in the 1970's and the opinion that "opportunities in the physical environment are the main reason of crime" has since been adopted. Locations where urban crimes are committed are mainly squatter areas, slums, illegally structured areas and neighborhoods of poverty in the city. The common characteristics of these areas are living conditions and characteristics that are sub-standards. Unfavorable and unhealthy conditions are dominant in and around buildings. Unqualified urban pattern, lack of comfort, dilapidation, extreme poverty, excess of structures that are empty, abandoned, unused and having lost their function, over occupancy apartment buildings, streets full of garbage and 
pollution. These plus the structure of settlement mixed with small and medium scale industrial and residential areas, schools that have lost their function with decreasing numbers of attendants, lack of recreation areas, dark, narrow, unpatrolled blind alleys with organic form, and lack of a traditional neighborhood structure can be cited among characteristics of physical environments where crime is common (Stewart [3]). However, although it is true that areas with sub-standard living conditions prepare environments favorable for crime, defining all social groups living in these areas as "potential criminals" is absolutely wrong. What is meant here is that these areas create a suitable background and climate for crime; this theory is not aimed or intended to leave all social groups under suspicion. Bourdieu [4] describes this condition as "a spectacular district symbolically sanctifying its residents while collection of a population homogenous in terms of deprivation reinforcing such deprivation". In this manner, this population group draws down all its own values with the pressures that it faces in public life. Gölbaşı [5] also draws attention to another dimension of the subject with a similar perspective: The conception viewing outskirts as places that threaten social peace and security and their residents as potential criminals serves neglecting 'white collar crimes' that are harmful for the society at least as much as crimes such as theft and stealing by snatching assumed to be committed by those parts of the society.

A comprehensive survey conducted by Eck [6] revealed that changing the location of the criminal did not have a strong effect on decreasing crime rate. In Eck's opinion, the criminal may change the location, time and type of crime, but he continues to commit crimes wherever he is. For this reason, the aim should not be changing the location of criminals, as has been tried many times, but by preventing crimes through improvement and regeneration of his living area. From this perspective, it can be concluded that the basic goal of urban regeneration in decreasing and preventing urban crime is improvement of living conditions and characteristics of these areas. Within the framework of this goal, the opportunity to benefit from the regeneration methods cited above is possible. At this point, it seems beneficial to remember Hague [7] emphasizing that due to its connections with poverty, regeneration in urban areas should not be taken into consideration as a residential matter with limited scope. According to Hague, the reason for this is that poverty displays differences between young and old people, newcomers and residents that are in the area for a long time, women and men or different ethnic groups. It is possible to conclude from this opinion that crime has direct or indirect organic relations with these differences and that the basic goal of regeneration is decreasing and preventing crime and criminality. Rako [8] points out that urban regeneration programs are primarily conducted in areas characterized with "dereliction, petty crime and negative perceptions". Clearance, revitalization, renewal, rehabilitation, gentrification, redevelopment and regeneration may be used as tools to prevent crimes and criminality according to unique features of the area. Only improving the area as a policy, displacing and dispersing crime nests and crowds of people from the areas that they live in are significant steps for decreasing crime and criminality. However, this step may not be a solution by itself most of the time. Today "crime and 
regeneration" is a new field of study. Coming up with social policies, improving educational and business opportunities and implementing concepts such as social harmony and social justice will be essential to the prevention of crimes. The factors cited here are directly related with basic goals of urban regeneration such as social sustainability and improvement of socioeconomic and cultural structure. Cities will continue to be the living area of crime and criminals unless regeneration in the social sense is achieved Ozden et al. [9].

\section{The relationship between urban space and crime in Istanbul}

Istanbul underwent a rapid process of spatial regeneration starting from Reforms in the Ottoman era. The first actions of planning were made with the start of the Republic, but these efforts remained quite limited due to economic and technical problems. Migration from rural areas to big cities in the 1950's affected Istanbul the most. The problem of shelter, which increased in an unexpected manner, could not be resolved by the government and consequently illegal housing became the dominant trend for the supply of houses. This situation continued in the same manner during the 1980's and the share of illegal areas in the city increased further with the numerous amnesties for zoning plans. Reflections of this unfavorable spatial regeneration on society in the social sense are worth discussing. The social fractions living in these illegal areas faced significant problems integrating into the city, in short, spatial disintegration led to social disintegration as well. The concept of globalization, which started to be felt more strongly in the 1990's in Istanbul and the organization of globalization with big projects and investments in Istanbul led to sharp movements of lands and the value of lands, and spatial disintegration became even more distinctive. These social and spatial disintegrations had a significant role on the gradual increase of urban conflict and strains. Urban regeneration and gentrification starting in the 2000's started to be implemented with methods that totally neglect social dimension and the danger of displacement threatens social groups. The biggest danger at this point is that the population groups that already suffer from social exclusion are forced through a new social exclusion process via designation of their situation by the urban governors.

When today's Istanbul is analyzed, it is observed that there is a gradual increase and intensification of crime rates in especially cosmopolitan areas of the city, central areas, transportation focus points and settlements with dense populations. Istanbul ranks first among cities where crime is most dispersed over a space. The Report of General Directorate of Security [10] revealed that the rate of increase in crime rates between 2003 and 2004 was 15\%, while the rate of increase of crime rates was $40 \%$ between 2000-2004. Furthermore, one fourth of all crimes committed in Turkey in 2004 were committed in Istanbul, while almost half of all crimes in the country in general were committed in Istanbul in 2005.

Research conducted in two different districts of Istanbul by Özden et al. [9], which was a former step of this study, suggested the relationship between crime and location in a significant manner. The locations were divided into good, 
average and bad regions by overlapping socioeconomic and physical characteristics according to the analytical studies conducted by municipalities; neighborhoods with the highest crime rates were marked. When categorizing the areas, six basic criteria were taken into consideration: social, demographic, spatial $(1,2,3)$ and criminological data. The conclusions of this study revealed results in both areas that support the relationship of urban space and crime of the Chicago School. Crimes are most intensive in the periphery of regions that are described as bad regions in the socioeconomic and physical sense.
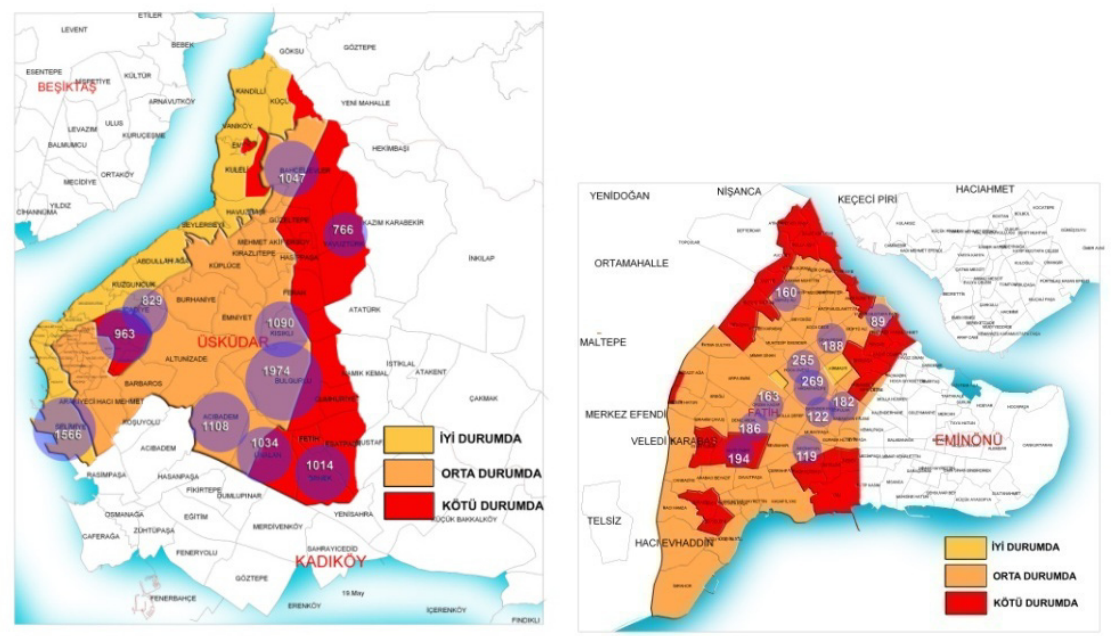

Source: Özden et al.

Figure 1: Relationship between space and crime in Uskudar.

Figure 2: Relationship between space and crime in Fatih.

\section{Urban crime and location relationship: an investigation through the districts of Beyoğlu and Ümraniye}

This study is the continuation of research conducted in 2007 in Fatih and Üsküdar, sub-districts of Ümraniye and Beyoğlu districts which have high crime rates and display a tendency of increase. The crime rates in both districts are above the average in Istanbul (Table 1).

The study was conducted on the basis of five basic data sets taken as the basis in the previous stage as well: (Social Data: Level of education of residents of the district, duration of time that they live there and status of content from the area, Demographic Data: Development of population in the district and intensive regions in terms of night time-day time population, Spatial Data -1 :Regions of the district with lower quality that are worn and dilapidated, Spatial Data -2 : Parts of the district missing in terms of fitting areas, Spatial Data -3: Status about use of residences in the district, Criminological Data: Regions of the district 
Table 1: Demographics and crime in Beyoğlu, Ümraniye and Istanbul at-large.

\begin{tabular}{|l|l|l|l|}
\hline Use of land & Beyoğlu & Ümraniye & Istanbul \\
\hline $\begin{array}{l}\text { Characteristics of } \\
\text { residences }\end{array}$ & $\begin{array}{l}\text { Mostly } \\
\text { Regular }+ \\
\text { Irregular }\end{array}$ & $\begin{array}{l}\text { Mostly Irregular } \\
\text { + Regular }\end{array}$ & $\begin{array}{l}\text { Mostly Irregular } \\
\text { + Regular }\end{array}$ \\
\hline $\begin{array}{l}\text { Population with an } \\
\text { elementary school } \\
\text { level education or } \\
\text { lower }\end{array}$ & 0.62 & 0.62 & 0.56 \\
\hline $\begin{array}{l}\text { Population under } \\
25\end{array}$ & 0.42 & 0.55 & 0.46 \\
\hline $\begin{array}{l}\text { Crime rate in 2000- } \\
\text { 2005 per 10,000 } \\
\text { residents }\end{array}$ & 127 & 67 & 64 \\
\hline
\end{tabular}

Source: Yirmibeşoğlu and Ergun [11]

intensive in terms of crime). However, spatial data are expressed under a single heading in this study due to page restriction.

\subsection{Relationship between crime and space in the district of Ümraniye}

Ümraniye, included within the scope of the study as a sample from the Anatolian part of the city, is comprised of 14 neighborhoods. Ümraniye, which remained as a village until 1960, let in immigrants intensively after it was announced as an organized industrial zone. It became a municipality in 1987. Located on the eastern side of Istanbul, it underwent rapid developments in the 1970's with intensification of the industrial sector in particular and soon started to provide service to neighboring settlements with its developments in the service and trade sectors. It let in migrations to a significant extent in 1980-1990 (Turgut et al. [12]). Numerous residence and shopping mall projects implemented in the region lately have played a significant role in an increase of physical characteristics of the region. It is one of the centers that were affected with the intensive residence spurts, especially in the 2000's. It should also be noted that the neighborhoods of this district are divided in terms of religious, political and also ethnic aspects. As such, social decomposition exists and the feeling of belonging could not develop.

\subsubsection{Social data: level of education of residents of the Ümraniye district, duration of their living there and level of contentment}

The district of Ümraniye had a village status until the 1960's, at which point it started to let in migrations intensively from Anatolia after it was announced as an 
Organized Industrial Zone in the 1960's. Its population started to increase more rapidly after it became a district in 1987. More than half of the residents in the area are graduates of primary / elementary school.

\subsubsection{Demographic data: development of population in Ümraniye and intensive regions in terms of daytime vs., night time population}

The district is an area where the young population is quite large. Approximately $55 \%$ of the population can be categorized as young people. The population density during the daytime is high in the region, which is a central business area (Table 2, Figure 3).

Table 2: $\quad$ Development of the population in Ümraniye in Years.

\begin{tabular}{|l|l|}
\hline Year & Population \\
\hline 1940 & 510 \\
\hline 1955 & 1781 \\
\hline 1970 & 22969 \\
\hline 1975 & 38730 \\
\hline 1980 & 71954 \\
\hline 1985 & 131495 \\
\hline 1990 & 242091 \\
\hline 1997 & 397359 \\
\hline 2000 & 605855 \\
\hline 2007 & 799313 \\
\hline
\end{tabular}

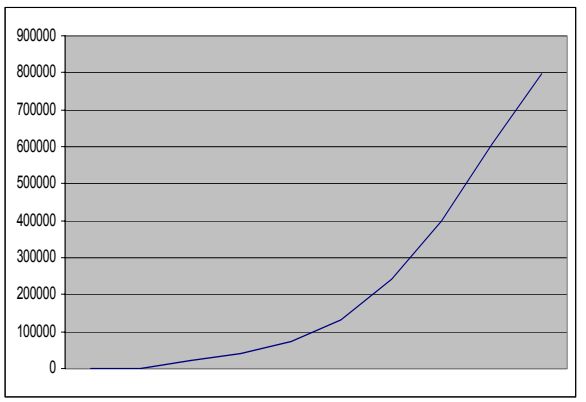

Figure 3: Development graphic of population in Ümraniye in Years.

\subsubsection{Spatial data}

(Spatial Data 1: Regions of the district with lower quality that are worn and dilapidated, Spatial Data 2: Parts of the district missing in terms of fitting areas, Spatial Data 3: Status about use of residences in the district)

The district displays quite an insufficient profile in terms of fittings. Especially the ratio of open spaces and green areas to the population is much lower than standards. 


\subsubsection{Criminological data}

When crimes committed in 2007 are analyzed, it is observed that the highest ratio of crimes committed in the district correspond to crimes committed related to goods with a ratio exceeding $70 \%$. This is followed by crimes committed against persons with a ratio of $18 \%$ (General Directorate of Security, [10]).

By analyzing these data, it is possible to show the relationship between space and crime in Umraniye as shown below (Figure 4):

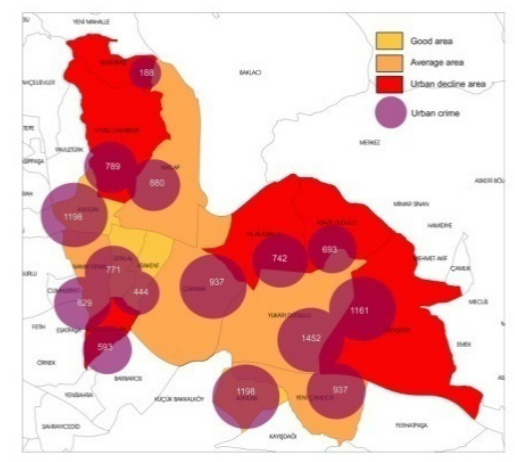

Figure 4: $\quad$ Relationship between Space and Crime in Ümraniye.

\subsection{Beyoğlu district and crime}

\subsubsection{Social data: level of education of residents of the Beyoğlu district, duration of residency there and level of content from the area}

Two different structures were formed in the district in terms of socioeconomic and cultural features by the Tarlabaşı Boulevard cutting and dividing the area into two parts. This decomposition has led to a structure incorporating very different groups in terms of socioeconomic profile, who are also disintegrated in a spatial sense as well. For this reason, an assessment of the level of content in the area is not very easy. While the level of content is quite high in regions such as Galata, Cihangir, and Gümüşsuyu, where mostly the higher class and intellectuals are settled, the level of content falls sharply when one goes to regions such as Kasımpaşa and Tarlabaşı, where physical conditions are substandard. The situation is even more interesting when duration of residency the area is analyzed: Although the duration of residency is limited to just a few years in districts such as Galata, Tünel, Cihangir, the process is going through a process of gentrification. Duration of residency is expressed in terms of decades in regions with low level of content where quality of structures is quite low and physical environmental conditions are bad. The reason for this is due to the fact that members of this second group are firmly clasped to each other and that they don't have the effort or power to try other ways of living. Moreover, they face the problem of marginalization and prejudice towards their varying ethnic and political profiles. Seventy-percent of the population that is literate in Beyoğlu is comprised of graduates of primary schools. The ratio of university graduates is 
only $4 \%$. These ratios are distributed in the form of different sets in two different parts of Beyoğlu. The ratio of the young population is high in the region (TÜIK [13]).

\subsubsection{Demographic data: development of population in the district and intensive regions in terms of daytime vs. night time population}

In contrast to Ümraniye, the population of the Beyoğlu district remained constant for many years and even underwent sharp decreases during certain periods. Except for certain regions undergoing a process of gentrification, Beyoğlu is gradually losing its residents while it has a very intensive population at night in İstiklal and Siraselviler Streets and Talimhane (Table 3, Figure 5).

Table 3: $\quad$ Population in Beyoğlu in years.

\begin{tabular}{|l|l|l|l|l|l|l|l|l|}
\hline Year & 1927 & 1940 & 1945 & 1950 & 1955 & 1960 & 1965 & 1970 \\
\hline Population & 236,141 & 247,252 & 257,091 & 279,238 & 208,138 & 216,425 & 218,985 & 225,85 \\
\cline { 1 - 6 } Year & 1975 & 1980 & 1985 & 1990 & 1997 & 2000 & 2007 & \\
\cline { 1 - 5 } Population & 230,532 & 223,36 & 245,999 & 229,00 & 231,826 & 231,90 & 213,471 & \\
\hline
\end{tabular}

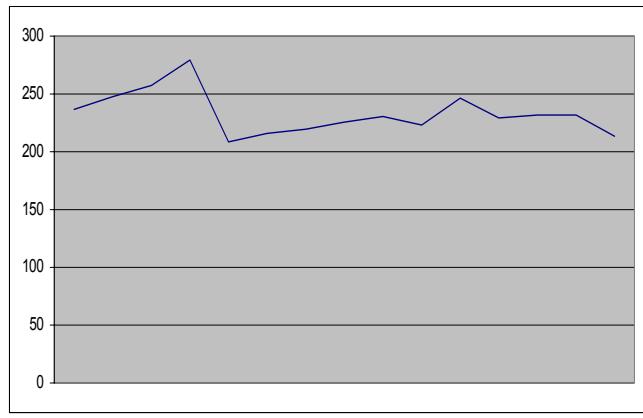

Figure 5: $\quad$ Population Development Profile of Beyoğlu District (1927-2007).

\subsubsection{Spatial data}

(Spatial Data 1: Regions of the district with lower quality that are worn and dilapidated, Spatial Data 2: Parts of the district missing in terms of fitting areas, Spatial Data -3: Status about use of residences in the district,

The most significant problem that Beyoğlu must deal with today is "poverty". Despite the high ratio of historical buildings in the district, its physical dilapidation and lack of population at night in certain parts increases dilapidation over time. As mentioned above, one part of Beyoğlu is divided into two parts by Tarlabaşı Boulevard, with one part undergoing a process of regeneration and gentrification while the other part is subject to poverty, social marginalization, isolation from society and physical dilapidation. Kesal [14] expresses the situation with striking language in a newspaper article: "Luminous neon lights on the Istiklal Street ... or illumination of Talimhane do not concern the residents of 
Kaptanpaşa, Fetihtepe, Bülbül Neighborhood, and Hacıahmet. People live with parasites and tuberculosis in houses one hundred meters behind Istiklal Street. Children still die from tuberculosis".

\subsubsection{Criminological data}

A total of 4,245 crimes were reported in 2007 to the General Directorate of Security in Beyoglu, which is one of the districts in Istanbul with the highest crime rate. Approximately $39 \%$ of all crimes were related to theft, $34 \%$ were crimes against civilians, $13 \%$ were narcotic related crimes and $8 \%$ were crimes against goods. These ratios are followed by traffic crimes at 3.5\%, financial crimes at $1.5 \%$, political crimes at $0.3 \%$ and social crimes at a ratio of $0.2 \%$. When records were compared to the previous year, it was observed that an increase of $400 \%$ occurred in rapes, $40 \%$ in prostitution and instigation for prostitution, $150 \%$ in narcotic crimes, especially in the sales of cocaine and ecstasy, $100 \%$ in smuggling of alcoholic drinks and $25 \%$ in certain political crimes that are detrimental for security of the society. The ratios of other crimes are lower when compared to the previous year. Compilation of these data reveals that the spatial distribution of crimes in the Beyoğlu region is as follows (Figure 6):

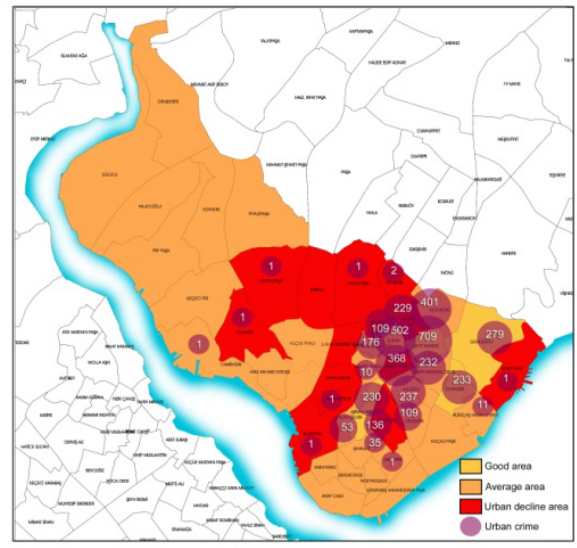

Figure 6: Relationship between Space and Crime in Beyoğlu.

\section{Assessment and conclusion}

Fast and uncontrolled regeneration of urban space caused by globalization increases crime ratios every day, and especially in big cities. Istanbul is one of the areas where urban disintegration is lived most in the social and spatial sense, especially the ratio of certain crimes as they increase further in the city. In Turkey, the struggle against crimes and criminals comprises of a system in which intervention is generally made after crimes are committed, whereby criminals are caught, handed over to law and punished. Since detailed determinations and 
assessments about crime and criminality are not made, development of police services preventing crime has not been possible. This method did not provide a definite solution to decrease the crimes committed and only provided provisional measures. In short classic implementations in struggle against crime do not provide adequate solutions and at this point urban regeneration is put forward as a tool. This study and the research conducted in Üsküdar and Fatih as its first step. Özden et al. [9] point at common conclusions and introduces the following relationships:

\subsection{Relationship between crime and space}

Spatial disintegrations and low quality spaces prepare the basis for crime.

Deserted, empty structures, irregular and uncontrolled green areas that are not well maintained or illuminated, and regions with complex road networks can easily be transformed into areas where gangs operate and become crime nests where they can organize.

Lack of recreation areas is a significant factor contributing to the young population living the problem of social isolation to commit crimes.

\subsection{Relationship between crime and socioeconomic profile}

Crime can easily develop among population groups with low socioeconomic profiles and where social disintegrations trigger crimes. Urban violence and clashes are concepts that encourage crime. High population density and uncontrolled increases of the population triggers crimes.

\subsection{Relationship between socioeconomic profile of areas and type of crime}

Crimes committed related to goods such as theft from houses, cars and offices are observed mostly in living areas occupied by the high and middle income groups, while crimes committed against persons such as wounding, extortion, quarrels, etc. occur mostly in areas where middle and lower income groups live.

All areas occupied by lower income groups are not potential areas for crime. Notwithstanding the foregoing, these areas are quite adequate for criminals to shelter. Thus, urban regeneration should be studied in two different dimensions, namely regeneration of physical space and regeneration of the social structure. This double sided regeneration should target minimization of social and spatial disintegration. Spatial and social regeneration should be used as a tool for preventing both crimes and criminality. Dilapidated, ruined, abandoned and uncontrolled areas suitable for committing crimes should be abrogated. Social regeneration programs to improve and regenerate criminals and the goal of including them in the local economy should be implemented.

\section{References}

[1] Adaman F. and Keyder Ç., Türkiye'de Büyük Kentlerin Gecekondu ve Çöküntü Mahallelerinde Yaşanan Yoksulluk ve Sosyal Dışlanma, Avrupa 
Komisyonu Çalışma, Sosyal İşler ve Fırsat Eşitliği Dairesi için hazırlanan rapor, 2005 (Poverty and Social Isolation in Squatter and Slum Areas of Big Cities in Turkey, report prepared for Labor, Social Works and Equality of Opportunity of the European Commission)

[2] Düzgün Ş., Suç Olgusuna Teorik Yaklaşımlar ve Disiplinlerarasılık (Theoretical and interdisciplinary approaches to the concept of crime), TMMOB Mimarlar Odası Ankara Şube Bülteni (Chamber of Architects, Bulletin of Ankara Branch), File 06, November-December 2007, p.4-10

[3] Stewart J. ve diğ. Local Government: Perceptions and Approaches to Urban Deprivation, Report on a Study Commissioned by the Home Office, Urban Deprivation Unit, 1974 Birmingham

[4] Bourdieu P., et al, Weight of the World: Social Suffering in Contemporary Society, (trans: Feguson P., P.), 1999 Cambridge

[5] Gölbaşı S., Kentleşme ve Suç, “İstanbul'un Kentleşme Süreci ile Suçluluk Arasındaki İlişkinin Kuramsal Değerlendirilmesi” (Urbanization and Crime, "Conceptual Evaluation of Urbanization Process of Istanbul and Criminality"), Levha Publications, January 2008, Istanbul

[6] Eck, J., E. "Preventing Crime at Places." Chapter Seven of Preventing Crime: What Works, What's Doesn't, What's Promising, ("The Sherman Report"). Washington, D.C.: National Institute of Justice Research Brief, July 1998.

[7] Hague C., Tackling Housing Regeneration and Housing Renewal, Istanbul 2004 International Regeneration Symposium: Workshop of Kucukcekmece District, 27-30 November 2004, 214-221

[8] Rako M., Remaking Place and Securitizing Space: Urban Regeneration and the Strategies, Tactics and Practices of Policing in the UK, Urban Studies, Vol. 40, No 9, 1869-1987, Carfax Publishing, August 2003

[9] Özden P., Un H.K., Ince Y, Kentsel Suç, Mekan ve Dönüşüm: Üsküdar ve Fatih İlçeleri Üzerinden Sorgulama, (Urban Crime, Location and Regeneration: An Investigation through districts of Üsküdar and Fatih,) V. Public Administration Forum, 18-20 October 2007, Umuttepe, KOCAELI

[10] Report of General Directorate of Security, 2004. Türkiye'nin Suç Haritası (Crime Map of Turkey)

[11] Yirmibeşoğlu F., Ergun N., İstanbul'da Suç, Kent ve Suç: Güvenli Kent, (Crime in Istanbul, City and Crime: Secure City) TMMOB Chamber of Architects, Bulletin of Ankara Branch, File 06, November - December 2007, p. 24-29

[12] Turgut S, Karakaş İ, Özden E. Ümraniye İlçesi’nde Üç Mahallenin Anatomisi (Anatomy of Three Neighborhoods in the district of Ümraniye), Ümraniye Municipality, 2002

[13] Turkish Statistics Institute, Data from 2000 Census Results

[14] Kesal E., Öteki Beyoğlu (Other Beyoğlu), Radikal Newspaper, 244.2005 